\title{
An investigation on factors influencing the intention to use e-money: A case study in Pontianak, Indonesia
}

\author{
Yuni Nustini*, Fariz Zhafiri \\ Department of Accounting, Universitas Islam Indonesia, Yogyakarta, Indonesia \\ *Corresponding author email: 903120102@uii.ac.id
}

\section{A R T I C L E I N F O}

\section{Article history:}

Available online

Keywords:

E-money, intension, developing region

DOI:

https://doi.org/10.20885/jaai.vol24.is $\underline{\text { s2.art4 }}$

\author{
A B S T R A C T
}

This study is to examine the factors influencing Pontianak citizens to use e-money in response to the state regulation. The investigated factors include perceived usefulness, perceived ease of use, perceived risk, and quality of service. Attitude toward the use of e-money was determined as the intervening variable to the intention to use e-money. Pontianak as a developing city in Borneo Island has been piloted to fully utilize electronic money to purchase fuel in gas stations. Meanwhile, so far Indonesians living in developing regions are not yet familiar with the advanced payment technology such as e-money. The samples were taken randomly from the gas station consumers in Pontianak. The number of samples collected was 100 and the data were processed using SmartPLS 3.0. The results of the study showed that all of the hypotheses were supported except perceived risk variable. In addition, the effect size of the intervening variable "attitude" in the relationships between perceived usefulness and the intention to use e-money as well as perceived ease of use and the intention to use e-money were categorized as full mediation. Meanwhile, the effect size of attitude in the relationship between quality of service and the intention to use e-money was categorized as quasi mediation. However, attitude did not have mediating effect on the perceived risk. The effect size of the mediating variable was proved large at the value of 1.981. Since the people of Pontianak represent those who were much familiar with cash transactions, the results of this study can be considered as an example for the implementation of e-money payment in other developing regions or for the execution of certain technology-based non-cash programs.

\section{Introduction}

The development of information and communication technology (ICT), especially the Internet, dramatically influences various aspects of human life. People nowadays tend to use various forms of electronic money (emoney). E-money promotes cashless business deals which are more convenient, safer, more accurate and efficient (Priambodo \& Prabawani, 2016). People do not need to bring large amount of cash that is susceptible to criminal acts. Bank of Indonesia as the regulator has issued Bank of Indonesia Regulation Number 11/12/PBI/2009 as the basis for the use of e-money in Indonesia. In megapolitan cities, e-money has been functioned as a payment mode as a practical solution, however, in small and developing communities, people have not yet habituated to using emoney.

Various facilities provided and the existence of government regulations managing the use of electronic money make the government and private sectors encourage people to switch from the conventional payment method (cash payment) to the use of e-money. In Jakarta, the capital city of Indonesia, this occurrence was evidenced by the enforcement to use commuter electronic ticketing to take commuter line (KRL) and E-money for Trans Jakarta city bus service as well as for toll payment managed by PT. Jasamarga since 31 October 2017 (Hamdi, 2017).

This study is important because it was conducted in the early period when the Pontianak city government enforced Pontianak people to use e-money in the gas stations. Since January 1, 2018, there has been a policy from the Pontianak city government that all people who make transactions at gas stations (SPBU) are required to use emoney, not cash payment. For this reason, this study aims to examine how people living in developing communities that are not familiar with e-money respond to the execution of using e-money when buying fuel as one of the people's basic needs. The result of this study can be used as a reference and example for the execution of any kind of advance technology payment method in other areas where the people are not yet accustomed to use it.

This research implemented Technology Acceptance Model (TAM) by Davis (1989) which is suitable with the topic of this study regarding the users' attitude and behaviour in the adoption of technology innovation, that is e-money. TAM states that there are two factors which influence users to accept technology innovation, those are 
perceived ease of use and perceived usefulness. Beside those two variables, this study accommodated two more factors into the research model, namely system quality as used by Olatukun and Oweoeye (2012) and perceived risk as used by Hussein and Saad (2016) and Roy et al. (2017). The dependent variable was the intention to use emoney, and the intervening variable was attitude toward using e-money. As a traditional type of people, perceived risk might become the most concerned factor for Pontianak citizens when dealing with technological aspects, while as a new method of payment the, quality of e-money application system was important that makes people do not feel reluctant to continuously use e-money after their first attempt. Thus, TAM is mostly employed since the model can effectively and suitably interpret and predict the user's acceptance of a new technological innovation.

\section{Literature Review}

TAM that was introduced by Davis (1985) was developed from Theory of Reasoned Action (TRA), a psychological model. TRA argues that an individual's perception toward something defines his/her attitude and behaviour. Some previous studies prove that the main factor of the successful system adoption is user acceptance. This theory consists of and is based on trust, attitude, and intention, which are then in TAM, they are developed into perceived usefulness and ease of use. Within TAM, these two variables allow us to understand user reaction when adopting information technology innovation.

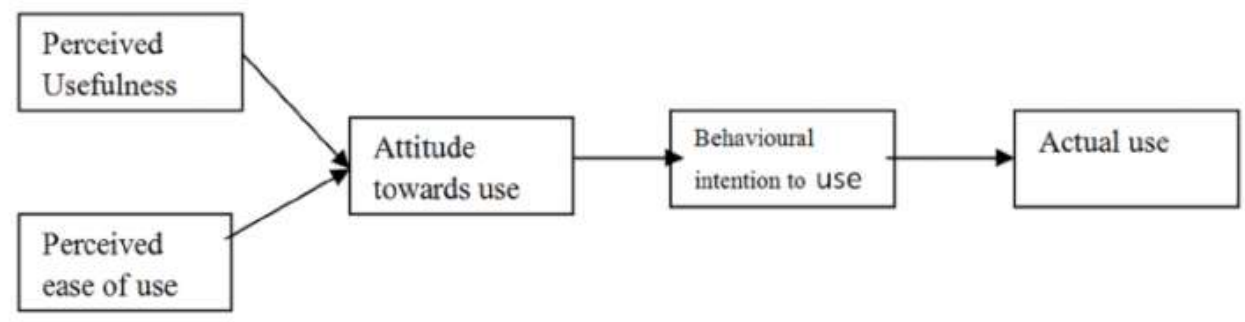

Picture 1. Theory Acceptance Model (Davis, 1989)

Bank for International Settlements (1996) defined e-money as a certain amount of money that was kept in an electronic device and had credit or prepaid value, and every time a transaction was made, the value was subtracted by the nominal value of the transaction. In Indonesia, the Central Bank (BI) issued Bank of Indonesia Regulation Number 11/12/PBI/2009 as a source of the utilisation of e-money. The regulation classifies e-money into two types, i.e. registered and unregistered e-money. Registered e-money means that the account holder is registered by an emoney operator and has the maximum limit of IDR 5,000,000, and the unregistered e-money means that the e-money operator does not need to register the account holder, and the maximum limit is IDR 1,000,000. Both registered and unregistered e-money have the maximum transaction of IDR 20,000,000 per month.

The research model that is advanced by the research hypothesis is built up on the basis of Technology Acceptance Model (TAM) and was first introduced by Davis (Davis, 1989). The following paragraphs elaborate the hypothesis development.

\section{The Influence of Perceived Usefulness on Attitude toward the Use of E-Money}

Perceived usefulness is defined by Davis (1989) as a degree to which an individual perceives that the new technology he/she implements will improve his/her performance. If an individual believes that a new system or technology that he/she uses is useful for him/herself, he/she will keep using it. Otherwise, if he/she does not believe it, he/she will stop using it. The previous studies found that perceived usefulness had a positive influence on user's attitude (Olatokun \& Owoeye, 2012; Fortuna, 2012; Priambodo \& Prabawani, 2016; Habibi \& Zaky, 2013; Hussein \& Saad, 2016).

Hypothesis 1: Perceived usefulness positively influences the attitude toward the use of e-money in Pontianak.

\section{The Influence of Perceived Ease of Use on Attitude toward the Use of E-Money}

Perceived ease of use is a degree to which an individual perceives that a technology is easy to use (Davis, 1989). Venkatesh and Davis (2003) divide ease of use into several aspects: easy to understand, less effort, easy to use, and fulfilling one's needs. In this study, perceived ease of use is related to whether or not e-money users easily learn, understand, and use e-money for fulfilling their needs. The previous studies found that perceived ease of use had a positive relationship with the systems being used (Davis, 1989; Priambodo \& Prabawani, 2016; Hussein \& Saad, 2016; Olatokun \& Owoeye, 2012).

Hypothesis 2: Perceived ease of use positively influences the attitude toward the use of e-money in Pontianak. 


\section{The Influence of Perceived Risks on Attitude toward the Use of E-money}

Purchasers might be worried regarding online safety and security in the use of their e-money and exposure of their personal information through the internet. Therefore, some people still doubt using online payment. Although they do on-line shopping, the traditional costumers choose to make cash payment, such as cash on delivery or online/offline banking transfer. The previous studies on credit card payment method discovered that one of the concerns related to buying online was fear of credit card fraud (Adnan, 2014; Abrar, Naveed, \& Ramay, 2017; Saprikis, Chouliara \& Vlachopoulou, 2010). The customers concerned about the perceived risk when making any online payment such as using e-money.

Perceived risk is a magnitude of unanticipated dissatisfaction and regret with the purchase or payment decisions based on the purchase objective, and hence it is an indication of consumer behaviour because consumers are more likely to minimize possible failures rather than to seek the purchase realization (Donni et al., 2018).

Pavlou (2001) points out three ways of measuring perceived risks, including previously known risks, possible loss, and unknown risks. Meanwhile, Arora and Kaur (2018) mentioned in their study that the dimensions of the perceived risk could be categorized into different six groups, namely time, financial, performance, social, security, and privacy. In the context of this study, perceived risks of the use of e-money include losing account balance with no reason and losing cards due to the lack of authentication for the use of e-money.

Regarding the role of perceived risk, Fortuna (2012) found that perceived risks had a negative influence on the use of e-money, and this finding was supported by Priambodo and Prabawani (2016). Furthermore, Roy et al. (2017) revealed that external risk had a negative influence on attitude towards internet banking. While Tham et al. (2019) concluded that financial risk and non-delivery risk have negative effect on online shopping behaviour. The previous research by Kuisma, Laukkanen, and Hiltunen (2007) stated that the customers were frightened of losing their money while carrying out the transaction from their accounts via the internet. Based on the abovementioned descriptions, it can be concluded that the higher the perceived risks, the lower the willingness to use emoney.

Hypothesis 3: Perceived risks negatively influence the attitude toward the use of e-money in Pontianak.

\section{The Influence of Quality of Service on Attitude toward the Use of E-money}

Bharati and Chaundhury (2006) state that the quality of a system is an individual's perception of the whole system as the manifestation of hardware and software. Users define a system as having good quality of service based on its ability to fulfil their expectations, which include practicality, ease of use, and time efficiency. If an individual finds that e-money allows users to make transaction more easily, practically, and efficiently, users will keep using it. Fortuna (2012) and Olatukun and Owaoye (2012) assume that quality of service positively influences attitude toward the use of e-money.

Hypothesis 4: Quality of service positively influences the attitude toward the use of e-money in Pontianak.

\section{The Influence of Attitude on the Intention to Use E-money}

In TAM, attitude toward using a technology is defined as an attitude toward the use of a system in the form of acceptance or refusal when a person uses a technology in his/her tasks (Davis, 1989). According to Jogiyanto (Fortuna, 2012), attitude is the amount of affection or feeling of an individual in accepting or rejecting an object or behavior that is measured using a method in which an individual is placed in a two-polar evaluative scale, such as good or bad, agree or disagree, and so on. The previous studies on user acceptance of internet banking show that attitude positively and significantly influences user's perception to use e-banking (Suh \& Han, 2002; Tjini \& Baridwan, 2013).

Hypothesis 5: Attitude positively influences the intention to use e-money in Pontianak.

\section{Research Method}

This study used primary data that were gathered by distributing randomly a set of questionnaires to Pontianak people who made fuel buying transaction at the gas stations. The number of data collected was 100, $70 \%$ came from Google Docs and $30 \%$ was taken directly by asking the people who purchased fuel at the gas stations to fill in the questionnaires. The research instrument put into a set of questionnaires consisted of open-ended statements whose response options were ranked into five scales, from scale 1 for 'strongly disagree' until scale 5 for 'strongly agree'. The items included in the questionnaires were adopted and adapted from many previous studies.

The dependent variable, intention to use e-money, measured to what extent an individual would use emoney again for making transaction. It was represented in four indicators in the questionnaire that were adapted from Olatokun and Owaoeye (2012). 
Table 1. Instrument for Intention to Use - Dependent Variable

\begin{tabular}{cl}
\hline Item & \multicolumn{1}{c}{ Intention to Use } \\
\hline P1 & I will keep using e-money for all my fuel purchase in Pontianak \\
P2 & I believe that I will use e-money more often in the future. \\
P3 & I prefer e-money to cash \\
P4 & $\begin{array}{l}\text { E-money's minimum risks make me sure that I will use it in other transactions } \\
\text { in the future. }\end{array}$
\end{tabular}

The first Independent Variable (IV), perceived usefulness, measured to what extent the system can improve an individual's performance, productivity level, effectiveness, and benefits from it. The indicators that were included in the questionnaire referred to those used by Utami (2016).

Table 2. Instrument for Perceived Usefulness - Independent Variable

\begin{tabular}{cl}
\hline Item & \multicolumn{1}{c}{ Perceived Usefulness } \\
\hline M1 & E-money allows me to make a transaction faster. \\
M2 & My performance improves by using e-money. \\
M3 & I can work more effectively by using e-money. \\
M4 & I feel more productive when using e-money. \\
\hline
\end{tabular}

The second IV was perceived ease of use. According to Venkatesh and Davis (2000), perceived ease of use is divided into several dimensions, involving user interface that is clear and easy to understand; less effort required to interact with the system, ease of use, and the system's performance that can serve user needs. Referring to Utami (2016), these dimensions were included in five indicators.

Table 3. Instrument for Perceived Ease of Use - Independent Variable

\begin{tabular}{cl}
\hline Item & \multicolumn{1}{c}{ Perceived Ease of Use } \\
\hline K1 & I can easily learn to use e-money. \\
K2 & I can easily become a skilful user of e-money. \\
K3 & With e-money, I can make a transaction more easily. \\
K4 & Using e-money does not require much effort. \\
K5 & Top-uping E-money can be done easily. \\
\hline
\end{tabular}

Perceived risk was the third IV. This is a subjective estimation of the users for any uncertainties or possible loss from the use of e-money (Wijayanti, 2017). Referring to Wijayanti (2017), these dimensions were included in three indicators in the questionnaire.

Table 4. Instrument for Perceived Risks - Independent Variable

\begin{tabular}{cl}
\hline Item & \multicolumn{1}{c}{ Perceived Risks } \\
\hline R1 & I am worried about my e-money not working properly. \\
R2 & I am worried about balance being deducted with no reason. \\
R3 & I find many risks in using e-money. \\
\hline
\end{tabular}

Quality of service (can be called as system quality and service) is the system ability at producing and providing accurate, efficient, and required service (Utami, 2016). In the context of this study, quality of service does not only include transaction process but also user subjective estimation about the bank service provided whenever e-money related problem occurs. There were six indicators for this variable referring to Utami (2016).

Table 5. Instrument for Quality of Service - Independent Variable

\begin{tabular}{cl}
\hline Item & \multicolumn{1}{c}{ Quality of Service } \\
\hline L1 & I can use e-money quickly. \\
L2 & I have never encountered any system failure when using e-money. \\
L3 & I do not find difficulty to check my e-money balance. \\
L4 & Information on e-money packaging is easy to understand. \\
L5 & Bank quickly responds to my problems in using e-money. \\
L6 & Bank provides any information I need when using e-money. \\
\hline
\end{tabular}

In this study, attitude served as the intervening variable. Attitude is an individual's judgment on whether or not the use of e-money is beneficial. This variable was measured using four indicators based on the questionnaire designed by Olatokun and Owaoeye (2012). 
Table 6. Instrument for Attitude - Intervening/Mediating Variable

\begin{tabular}{cl}
\hline Item & \\
\hline S1 & Using e-money is a good idea. \\
S2 & Using e-money is fascinating. \\
S3 & E-money provides comfort in transaction. \\
S4 & E-money allows me to manage my financial matters. \\
\hline
\end{tabular}

An intervening variable mediates the relationship between dependent and independent variables. According to Baron and Kenny (1986), there are three possibilities of how an intervening variable mediates such relationship, namely: full mediation, quasy mediation, and no mediation effects.

\section{Results and Discussion}

\section{Profile of the Respondents}

The descriptive statistic test was conducted using SPSS version 20. The number of the data collected was 100 . The profile of the respondents can be illustrated as follows. Men dominated the samples, which were $65 \%$ of the 100 respondents, $64 \%$ were at the age of $20-40$ years old; $75 \%$ were employees or entrepreneurs and the rest were students or homemakers. There were $59 \%$ of the participants who had one or more cars; $96 \%$ of the respondents had one or more motorcycles, and $4 \%$ had no motorcycle. $73 \%$ of the participants bought fuel twice or more in a week, while $27 \%$ bought once in a week.

\section{Reliability, Convergent Validity, and Discriminant Validity}

This study utilized Smart Partial Least Squares 3 (SPLS M3) to perform the tests. In the outer model analysis, the research model, variables, and items were assessed by examining the reliability, convergent validity, and discriminant validity. The Table 7 shows the results of the tests.

Table 7. Outer Loading

\begin{tabular}{|c|c|c|c|}
\hline Variable & Code & Outer Loading & AVE \\
\hline \multirow{4}{*}{ Perceived usefulness (PM) } & M1 & 0.896 & \multirow{4}{*}{0.822} \\
\hline & M2 & 0.911 & \\
\hline & M3 & 0.928 & \\
\hline & M4 & 0.889 & \\
\hline \multirow{5}{*}{ Perceived ease of use (PK) } & $\mathrm{K} 1$ & 0.755 & \multirow{5}{*}{0.595} \\
\hline & $\mathrm{K} 2$ & 0.689 & \\
\hline & K3 & 0.827 & \\
\hline & K4 & 0.796 & \\
\hline & K5 & 0.783 & \\
\hline \multirow{3}{*}{ Perceived risks (PR) } & R1 & 0.888 & \multirow{3}{*}{0.796} \\
\hline & $\mathrm{R} 2$ & 0.827 & \\
\hline & $\mathrm{R} 3$ & 0.861 & \\
\hline \multirow{6}{*}{ Quality of service (KP) } & L1 & 0.794 & \multirow{6}{*}{0.612} \\
\hline & $\mathrm{L} 2$ & 0.650 & \\
\hline & L3 & 0.823 & \\
\hline & L4 & 0.772 & \\
\hline & $\mathrm{L} 5$ & 0.831 & \\
\hline & L6 & 0.809 & \\
\hline \multirow{4}{*}{ Attitude (S) } & S1 & 0.916 & \multirow{4}{*}{0.791} \\
\hline & $\mathrm{S} 2$ & 0.931 & \\
\hline & S3 & 0.931 & \\
\hline & S4 & 0.769 & \\
\hline \multirow{4}{*}{ Intention to use (KM) } & P1 & 0.864 & \multirow{4}{*}{0.783} \\
\hline & $\mathrm{P} 2$ & 0.904 & \\
\hline & P3 & 0.893 & \\
\hline & $\mathrm{P} 4$ & 0.878 & \\
\hline
\end{tabular}

The findings confirmed that the loading of each item was well and above the threshold 0.70 (Ghozali \& Latan, 2015), except for 2 items, K2: 0.689 and L2: 0.650 , both loading factors were very close to 0.70 . However, some accept the threshold 0.60. That means that the indicators were valid (Ghozali \& Latan, 2015) without the need for removing any indicator. In addition, the Average Variance Extracted (AVE) that measured the convergent validity was expected to be more than 0.5 (Ghozali \& Latan, 2015), and it was also fulfilled. 
Table 8 shows the results of the inter-construct correlation. It can be seen that the square root of AVE from each construct of the latent variable was higher than the value of the inter-construct correlation in the model, where all of the values were $<0.85$. A result less than 0.85 tells us that the discriminant validity likely exists between the two inter-constructs.

Table 8. Discriminant Validity

\begin{tabular}{|c|c|c|c|c|c|c|}
\hline & $\begin{array}{l}\text { Intention to use } \\
\qquad(\mathrm{KM})\end{array}$ & $\begin{array}{l}\text { Quality of } \\
\text { service (KP) }\end{array}$ & $\begin{array}{c}\text { Perceived ease of } \\
\text { use (PK) }\end{array}$ & $\begin{array}{c}\text { Perceived } \\
\text { usefulness (PM) }\end{array}$ & $\begin{array}{l}\text { Perceived } \\
\text { risks (PR) }\end{array}$ & $\begin{array}{l}\text { Attitude } \\
\text { (S) }\end{array}$ \\
\hline $\mathrm{KM}$ & 0.885 & & & & & \\
\hline $\mathrm{KP}$ & 0.838 & 0.782 & & & & \\
\hline PK & 0.770 & 0.755 & 0.772 & & & \\
\hline PM & 0.727 & 0.758 & 0.654 & 0.906 & & \\
\hline PR & -0.342 & -0.456 & -0.276 & -0.484 & 0.892 & \\
\hline $\mathrm{S}$ & 0.815 & 0.827 & $0.781 * * *$ & $0.733 * *$ & $-0.493 *$ & 0.890 \\
\hline
\end{tabular}

Structural model is intended to identify the cause and effect of each latent variable; the measure is Rsquare. The reliability was measured using composite reliability. Looking at the results, the lowest composite reliability (CR) was 0.880 in perceived ease of use, while the highest was 0.949 in quality of services. It means that all variables were reliable since the values of CR was good if they were above 0.7 (Ghozali, 2016). Table 9 lists the $\mathrm{R}$-square results of attitude and intention to use e-money as well as composite reliability of every variable. Rsquare measures the goodness-of-fit in a linear regression model. It predicts the percentages of independent variables' influences that is able to collectively explain the dependent variable. Attitude was $75.9 \%$ influenced by perceived usefulness, perceived ease of use, perceived risk, and quality of services. The remaining percentage of $24,1 \%$ was explained by other variables. Meanwhile, intention to use was $76 \%$ influenced by attitude, and the rest could be explained by other variables. Furthermore, if the number of scale items of Composite Reliability is smaller, it tends to result in lower reliability levels of the variables. Composite Reliability reasonable threshold is 0.60 upwards. This research confirmed that the entire tests met the satisfactory values.

Table 9. R-square and Composite Reliability

\begin{tabular}{lcc}
\hline \multicolumn{1}{c}{ Variable } & R-square & Composite Reliability (CR) \\
\hline Perceived usefulness (PM) & & 0.935 \\
Perceived ease of use (PK) & & 0.904 \\
Perceived risks (PR) & & 0.880 \\
Quality of service (KP) & 0.759 & 0.949 \\
Attitude (S) & 0.760 & 0.921 \\
Intention to use (KM) & & 0.938 \\
\hline
\end{tabular}

\section{Hypothesis Testing}

The hypothesis testing was conducted by considering p-value to define the significance level of the correlations among the latent variables. The decision was made based on both the positiveness of the negative signs of the original samples and the significance level of the testing model. This study applied the confidence level of $95 \%$ or the significance level of $5 \%$. With such level, there was one hypothesis - $\mathrm{H} 3$ that was not supported by the data, but the other four hypothesis were supported by the data. The results of the tests can be found in Table 10, and the explanation of each hypothesis will be elaborated in the next paragraphs.

Table 10. Hypothesis Testing Result

\begin{tabular}{clccl}
\hline Hypothesis & \multicolumn{1}{c}{ Path } & Original sample & $\mathrm{p}$-value* & \multicolumn{1}{c}{ Decision } \\
\hline H1 & Perceived usefulness $\rightarrow$ Attitude & 0.157 & 0.049 & Supported \\
H2 & Perceived ease of use $\rightarrow$ Attitude & 0.346 & 0.000 & Supported \\
H3 & Perceived risks $\rightarrow$ Attitude & -0.080 & 0.231 & Not supported \\
H4 & Quality of service $\rightarrow$ Attitude & 0.412 & 0.001 & Supported \\
H5 & Attitude $\rightarrow$ Perceived Use & 0.265 & 0.018 & Supported \\
\hline
\end{tabular}

\section{Discussion}

Hypothesis 1: Perceived usefulness positively influences the attitude toward the use of e-money. 
The results of the study showed a positive beta value of 0.157 , which means that perceived usefulness positively influences the attitude toward the use of e-money; and the p-value was $0.049<0.05$. It is concluded that this variable is significantly influential for the attitude.

Wijayanti (2017) states that perceived usefulness is related to the productivity and effectiveness of a system which benefit to improve the user's performance. When the user feels that there are many benefits which can be fetched from e-money, the user will have more positive attitude toward it. This result is in line with Priambodo and Prabawani's study (2016) confirming that perceived usefulness influences the attitude toward the use of e-money. Hussein and Saad (Utami, 2016; Suhud et al. 2019) conclude that there is a significant influence of perceived usefulness on attitude and e-money adoption intention. Thus, the first hypothesis is supported.

Hypothesis 2: Perceived ease of use positively influences the attitude toward the use of e-money.

The original sample value of this variable was 0.346 with $p$-value of 0.000 which means that perceived ease of use has a positive and significant influence on the attitude toward the use of e-money. This relationship works in the way that an individual will use a system if he/she finds it easy to operate and vice versa (Davis, 1989). In the context of this study, it was easy to purchase fuel by using e-money in the gas stations in Pontianak, thus, the attitude toward the use of e-money became positive. This result is in line with Olatukun and Owoeye (2012) as well as Hussein and Saad (Utami, 2016) which argue that perceived ease of use positively influences the attitude toward the use of Internet banking. Suhud, Budak, and Benk (2019) suggest that there is a significant influence of perceived ease of use on attitude and e-money adoption intention. Thus, the second hypothesis is supported.

Hypothesis 3: Perceived risks negatively influence the attitude toward the use of e-money.

The beta value of this variable was -0.080 which means that perceived risks were negatively related to the attitude toward the use of e-money. Since the p-value of this variable was $0.231>0.05$, the influence of perceived risks was not significant. Moudi (2014) suggests that consumers' perceived risks have a significantly negative effect on consumers' attitudes and intentions to shop in the internet. An individual tends to have perceive risks when there is an uncertainty for the possible outcomes. Thus, users cannot easily be sure to use e-money. As users learn more positive information about e-money, there will be fewer risks, and this leads to more possibilities to use e-money (Wijayanti, 2017). The most vital aspect of the internet banking is the security risk associated to the possible loss because of shortages in the functioning system or embezzlement of resources via illegitimate exterior entry (Fadare, 2016). There exists a significantly negative relationship between time risk (TR) and intention to use e-money. Time risk can also be identified with the period included in managing with wrong dealings.

The result was predictable since the use of e-money in Pontianak was obligatory regardless the fact that people were not aware of any possible risks yet. As the study found that perceived risks had a negative and insignificant influence on the attitude toward the use of e-money, the third hypothesis is not supported.

Hypothesis 4: Quality of service positively influences the attitude toward the use of e-money.

Based on the results of the study, the original sample value was 0.412 which means that quality of service was significantly positively influenced the attitude toward the use of e-money. With $p$-value of 0.001 , this variable was significantly influential for the attitude. Good quality of service from the e-money service providers can increase the use of e-money not only for purchasing fuel. This finding is in line with Fortuna (2012) and Utami (Utami, 2016), and thus the fourth hypothesis is supported.

Hypothesis 5: Attitude toward the use of e-money positively influences the intention to use e-money. The results of the study showed that the beta value of the variable was 0.265 with the significance level of 0.000 . Thus, it can be concluded that attitude was significantly positively influence the intention to use e-money. This is in line with Olatukun and Owoeye (2012) as well as Suhud et al. (2019); thus, the fifth hypothesis is supported.

\section{Test of Intervening Variable}

According to Baron and Kenny (1986), there are two analysis models to examine the influence of an intervening variable on the correlations between dependent and independent variables, namely type analysis and effect size analysis. Bootstrapping test was conducted to examine how attitude as the intervening variable influenced the relationships between each of the independent variables and the dependent variable, the summary is presented in Table 11.

Table 11 can be explained as follows.

a. Attitude acts as quasi mediation for the relationships between quality of service and intention to use e-money. It is because quality of service could significantly influence attitude as well as intention to use e-money without the intervention of attitude.

b. Attitude acts as full mediation for the relationships between perceived ease of use and intention to use emoney. Perceived ease of use significantly influences attitude but not intention to use e-money.

c. Attitude does not mediate the relationships between perceived risks and intention to use e-money. It is because perceived risks does not significantly influence either attitude or intention to use e-money.

d. Attitude fully mediates the relationships between perceived usefulness and intention to use e-money because attitude does not significantly influence intention to use e-money. 
Table 11. Results of Analysis on Types of Intervening Variable

\begin{tabular}{|c|c|c|c|c|}
\hline Path & $\begin{array}{l}\text { Original } \\
\text { sample }\end{array}$ & p-Value & Result & $\begin{array}{c}\text { Type of Intervening } \\
\text { Variable }\end{array}$ \\
\hline Quality of service $\rightarrow$ Intention to use & 0.412 & 0.000 & Significant & \multirow{2}{*}{ a. Quasi Mediation } \\
\hline Quality of service $\rightarrow$ Attitude & 0.411 & 0.000 & Significant & \\
\hline Perceived ease of use $\rightarrow$ Intention to use & 0.183 & 0.059 & Not Significant & \multirow{2}{*}{ b. Full Mediation } \\
\hline Perceived ease of use $\rightarrow$ Attitude & 0.346 & 0.000 & Significant & \\
\hline Perceived risks $\rightarrow$ Intention to use & 0.081 & 0.285 & Not Significant & \multirow{2}{*}{ c. No Mediation } \\
\hline Perceived risks $\rightarrow$ Attitude & -0.080 & 0.231 & Not Significant & \\
\hline Perceived usefulness $\rightarrow$ Intention to use & 0.140 & 0.067 & Not Significant & \multirow{2}{*}{ d. Full Mediation } \\
\hline Perceived usefulness $\rightarrow$ Attitude & 0.157 & 0.047 & Significant & \\
\hline
\end{tabular}

\section{Effect Size Analysis on Intervening Variable}

The test to attain the effect size $\left(\mathrm{f}^{2}\right)$ of the intervening variable, attitude, toward the intention to use e-money resulted in the value of 1.981 . This value means that attitude has a large moderating effect size (Cohen, 1988) toward the dependent variable, intention to use e-money. Moreover, attitude has a medium moderating effect size to three independent variables, those are quality of service, perceived ease of use, and perceived usefulness.

Table 12. Results of Effect Size Analysis on Intervening Variable

\begin{tabular}{lccl}
\hline \multicolumn{1}{c}{ Variable } & Intention to Use & Attitude & Effect Size $\left(\mathrm{f}^{2}\right)^{*}$ \\
\hline Attitude (S) & $(+) 1.981$ & & Large \\
Quality of Service (KP) & & $(+) 0.220$ & Medium \\
Perceived Ease of Use (PK) & $(+) 0.195$ & Medium \\
Perceived Usefulness (PM) & $(+) 0.039$ & Medium \\
Perceived Risks (PR) & $(+) 0.019$ & Small \\
*Note: Cohen (1988): $\mathrm{f}^{2}=0,02:$ small effect; $\mathrm{f}^{2}=0,15:$ medium effect; $\mathrm{f}^{2}=0,35:$ large effect.
\end{tabular}

\section{Conclusion}

The revolutionary development of ICT especially the internet has changed people all over the globe to migrate to modern life style. Everyone experiences the gradual substitution of the traditional method of cash payment with an electronic payment system. One of the recent payment methods is e-money, slowly forming its path to its massive exploitation. So far, the initiative of this path is evident in the developed countries or communities, where the technological advancement, as well as education, understanding, even the cultures are at the utmost level. On the other hand, in the more traditional or developing countries, the electronic banking or payment issues require an enactment and enforcement of a new legal code to build a cashless society that is proved more efficient, safer, and more convenient as a payment instrument.

The results of this study conclude that Pontianak people support the new pronouncement to use e-money for fuel transaction administered by the City Government. Having in mind that all kinds of innovation need a period for penetration, it can be expected that in time ahead, e-money will be accepted as the common payment instrument. Afterwards, the utilization of e-money will encourage the Pontianak people's payment behavior which will end up into the creation of a cashless society.

Attitude to use e-money in this study is influenced by perceived usefulness, perceived ease of use, and quality of service provided by the e-money issuers, but not by perceived risk to use e-money. When people find it beneficial to utilize e-money, people will be in agreement and happy to have e-money then motivate them to spend it. People start to feel comfortable and secured using e-money thus no longer depend on cash payment. In the case of Pontianak people, e-money will then be expended not only for fuel transaction, but also for many other transactions. Hence, by utilizing e-money, people of Pontianak will alter their payment behavior and create a cashless society.

The far distance between the reseacher (in Yogyakarta City) and the objects, joined together with the limited time and funds to do the research become three main concerns for this research. These limitations caused a constraint to get a lot of number of samples.

Two suggestions can be addressed for future studies. First, involving new variables especially individual factors that might express people awareness to use e-money; and, involving more participants from some other areas or locations with similar development characteristics. The regulations mandating the use of e-money must be enacted and enforced by the government if a cashless society is to be created. Some benefits of e-money is easy transportability and reasonable price application which offers extensive use in the trades among countries. It is presumed that the users of e-money will be encouraged with the cheaper transactions using foreign currencies. 


\section{References}

Abrar, K., Naveed, M., \& Ramay, M. I. (2017). Impact of perceived risk on online impulse buying tendency: An empirical study in the consumer market of Pakistan. Journal of Accounting \& Marketing, 6(3), 246. doi: $10.4172 / 2168-9601.1000246$

Adnan, H. (2014). An analysis of the factors affecting online purchasing behaviour of Pakistani consumers. International Journal of Marketing Studies, 6(5), 133148. http://dx.doi.org/10.5539/ijms.v6n5p133

Arora, S., Kaur, S. (2018). Perceived Risk Dimensions \& Its Impact on Intention to Use E-Banking Services: A Conceptual Study. Journal of Commerce \& Accounting Research, 7(2)

Bank for International Settlements. (1996). Implications for central banks of the development of electronic money. Bis, (October). Retrieved fromhttp://www.bis.org/publ/bisp01.htm

Bank Indonesia. (2009). Uang Elekrtonik (Elektronik Money), (11), 1-55.

Baron, R. M., \& Kenny, D. a. (1986). The Moderator-Mediator Variable Distinction in Social the ModeratorMediator Variable Distinction in Social Psychological Research: Conceptual, Strategic, and Statistical Considerations. Journal of Personality and Social Psychology, 51(6), 1173-1182. https://doi.org/10.1037/0022-3514.51.6.1173

Bharati, P., \& Chaudhury, A. (2006). Product Customization on the Web: An Empirical Study of Factors Impacting Choice board User Satisfaction. Information Resources Management Journal, 19(2), 69-81. https://doi.org/10.14670/HH-25.1239

Cohen, J. (1988). Statistical power analysis for the behavioural sciences (2nd ed.). Hillsdale, New Jersey: Lawrence Earlbaum Associates.

Damghanian, H., Zarei, A., \& Siahsarani Kojuri, M. A. (2016). Impact of perceived security on trust, perceived risk, and acceptance of online banking in Iran. Journal of Internet Commerce, 15(3), 214-238.

Davis. (1989). Perceived usefulness, perceived ease of use, and user acceptance of information technology. MIS Quarterly, 13(3), 319-340. https://doi.org/10.1016/S03050483(98) 00028-0

Donni, R., Dastane, O., Haba, H. F., \& Selvaraj, K. (2018). Consumer perception factors for fashion M-commerce and its impact on loyalty among working adults. Business and Economic Research

Fadare O. A. (2016). A Survey on Perceived Risk and Intention of Adopting Internet Banking. Journal of Internet Banking and Commerce, 21(1).

Fortuna, S. C. D. (2012). Pengaruh Faktor Individu, Organisasi, dan Sistem terhadap Penerimaan E-Banking. Jurnal IImiah Mahasiswa FEB, 1(2).

Ghozali, I., \& Latan, H. (2015). Partial Least Squares: konsep, teknik dan aplikasi menggunakan program SmartPLS 3.O (2nd ed.). Semarang: Penerbit Universitas Dipenogoro Semarang.

Habibi, M., \&Zaky, A. (2013). Pengaruh Kepercayaan, PersepsiKegunaan, PersepsiKemudahan, dan PersepsiKenyamanan Terhadap MinatPenggunaan Mobile Banking Syariah. Journal of Chemical Information and Modeling, 53(9), 1689-1699. https://doi.org/10.1017/CBO9781107415324.004

Hussein, A., \& Saad, M. (2016). Perceived risk and behavioral determinants of using internet banking in Egypt. Journal of Behavioural Economics, Finance, Entrepreneurship, Accounting and Transport, 4(3), 40-48.

Irmadhani, \&Nugroho, M. A. (2012). Pengaruh PersepsiKebermanfaatan, PersepsiKemudahanPenggunaan Dan Computer Self Efficacy, Terhadap Penggunaan Online Banking Pada Mahasiswa S1 FakultasEkonomi Universitas Negeri Yogyakarta. KajianPendidikan\&Akuntansi Indonesia, 1, 1-20. Retrieved from http://journal.uny.ac.id/index.php/jkpai

Jogiyanto. (2007). Sistem InformasiKeprilakuan. Yogyakarta: Andi Offset.

Kuisma T, Laukkanen T,Hiltunen M. (2007). Mapping the Reasons for Resistance to Internet Banking: A M meansEnd Approach. Internationa Journal of Information Systems

Olatokun, W., \& Owoeye, O. J. (2012). Influence of Individual, Organizational and System Factors on Attitude of Online Banking Users. Retrieved http:// proceedings.informingscience.org/InSITE2012/InSITE12p389-403Olatokun0111.pdf

Pahlevi, A. (2018). SPBU di Pontianak Terapkan E-Money - Bisnis Tempo. 
Pavlou P (2001) Integrating Trust in Electronic Commerce with the Technology Acceptance Model: Model Development and Validation. AMCIS Proceedings, Boston.

Priambodo, S., \& Prabawani, B. (2016). PersepsiRisiko Terhadap Minat Menggunakan LayananUang Elektronik (StudiKasuspadaMasyarakat di Kota Semarang) PendahuluanKajianTeoriPerilakuKonsumen. Jurnal IImuAdministrasiBisnis, 5(2).

Tham, K.W., Dastane, O., Johari, Z., Ismail, N. (2019). Journal of Asian Finance, Economics and Business, 6(4), 249-260

Tjini, S. A, \&Baridwan, Z. (2013). Kemudahan , dan PersepsiKenyamanan Terhadap MinatPenggunaan Sistem Internet Banking. Jurnal IImiah Mahasiswa FEB, 1(1), 1-21.

Saprikis, V., Chouliara, A., \& Vlachopoulou, M. (2010). Perceptions towards online shopping: Analyzing the Greek university students' attitude. Communications of the IBIMA, Article ID 854516 [Online Journal]. Retrieved from http://citeseerx.ist.psu.edu/viewdoc/ download?doi=10.1. 1.589.747\& rep

Suh, B., \& Han, I. (2002). Effect of trust on customer acceptance of Internet banking. Electronic Commerce Research and Applications, 1(3-4), 247-263. https://doi.org/10.1016/S1567-4223(02)00017-0

Suhud. U., Budak, T., Benk. S. (2019). Antecedents of e-money adoption intention among Indonesian and Turkish consumers. Management Science Letters 10 (2020). September 10, 2019doi: 10.5267/j.msl.

Utami, Ri. A. (2016). Pengaruh Kualitas Sistem dan Layanan, Kepercayaan, PersepsiManfaat, PersepsiKemudahan dan PersepsiRisiko terhadap SikapPenggunaan E- money. Universitas Islam Indonesia.

Venkatesh, V., Morris, M. G., Davis, G. B., \& Davis, F. D. (2003). User Acceptance of Information Technology: Toward a Unified View. Source: MIS Quarterly, 27(3), 425-478. https://doi.org/10.2307/30036540

Wijayanti, F. (2017). Pengaruh PersepsiManfaat, PersepsiKemudahan, Kepercayaan dan PersepsiResiko Terhadap Minat Menggunakan E-Money. Universitas Islam Indonesia. 